\title{
TOURISM AND WATER USE IN MALAYSIA: A REVIEW
}

\author{
Zuraini Anang1, Noorhaslinda Kulub Abdul Rashid ${ }^{2}$ \& Azlina Abd. Aziz ${ }^{3}$ \\ ${ }^{1,2,3}$ Faculty of Business, Economics \& Social Development, University Malaysia Terengganu \\ (zura@umt.edu.my, lindarashid@umt.edu.my, aqlina@umt.edu.my)
}

\begin{abstract}
Tourism is the economic driver for many emerging countries, and the main key distribution components of wealth in the world. Globally, tourism generated over 10\% of the world Gross Domestic Product (GDP) and provided an estimation of 115 million jobs in 2017. Moreover, the tourism sector consumed $1 \%$ of the global consumption of water. This paper reviews the current literature that focuses on water usage in tourism sector and water management initiatives in tourism in order to identify the current and future contrast between water demand and supply for sustainable tourism, and to understand the key issues and challenges facing water usage in Malaysia. Furthermore, the paper examines the linkages between tourism and water consumption, and analyses the trends in water consumption. The paper concludes by emphasizing the importance of improving and enhancing the existing water resources policies in order to conserve nature while promoting sustainable tourism industry.
\end{abstract}

KEYWORDS: water use, tourism, sustainable, management

\section{PURPOSE AND BACKGROUND}

Malaysia's tourism sector has become one of the largest contributors to Malaysia's GDP, which increased from $14.6 \%$ in 2017 to $15.2 \%$ in 2018. In 2018, the domestic visitors increased by about $7.7 \%$ and total domestic expenditures increased by $11.4 \%$ compared to the previous year in 2017 . Inbound travel and outbound travel expenditures increased by about 2.28\% and 5.77\%, respectively compared to 2017.

The tourism employment raised from 3.308 million to 3.471 million people who worked in the tourism sector (Department of Statistics Malaysia, 2019). These increases prove that tourism sector plays a major role in the economic development throughout many countries in the world including Malaysia. The tourism sector consumes $1 \%$ of the global consumption of water.

Freshwater is an important factor in performing tourism activities, such as ski or golf tourism, swimming, fishing, sailing, diving and kayaking. Tourists also consume water for baths, showers, washing and using the toilet whereas the tourism businesses needs water for gardening, irrigation, snowmaking and landscaping in the touristic areas. Tourism depends on water resources in various forms, such as winter tourism, agritourism and wildlife tourism.

Many countries have expansively been using water resources, with desalination being often used by some large industrialised countries such as United States, Italy and Spain. The freshwater imports with tanker ships have also become critical for the island states, such as Bahamas, Antigua and Barbuda, Mallorca, the Greek Island, Fiji and Tonga (UNESCO, 2009).

The important problems that need to be considered urgently are when the freshwater usage exceeds the availability of renewable water resources, leading to significant shares of renewable water use. Increase in tourist numbers, higher standards of hotel and tourism accommodations, and the increase in water-related tourism activities will cause higher water consumption in the tourism sector by 2020 (Gossling, 2012). 
As a result, the tourism management may not manage a proper water supply, jeopardiszing the function of the infrastructure related to water needs for the tourists. This paper reviews the current literature that focuses on water usage in tourism sector and water management initiatives in tourism in order to identify the current and future contrast between water demand and supply for sustainable tourism, and to understand the key issues and challenges facing water use in Malaysia.

\section{METHODOLOGY}

This study is a literature review of water usage in the tourism sector in Malaysia based on full-text journal articles, reports, and conference proceedings sourced from both electronic and non-electronic databases. In addition to this, the websites of organisations that have researched or addressed this issue were referred to for related documents and reports. Only documents written in English were considered.

\section{FINDINGS}

This research has affirmed that sustainable water usage in the tourism sector is a crucial issue because tourism is the important sector in economics as mentioned by United Nations Sustainable Development Goals (SDG), which is Goal 6: Clean Water and Sanitation. Moreover, the tourism sector is valued as the main sector to safeguard water resources by World Tourism Organization (UNWTO, 2014). The meaningful information can contribute to improve the water management in tourism sector and to tally with the water indicators on tourism accommodation, particularly on water availability, water conservation and drinking water quality as proposed by World Tourism Organization (UNWTO, 2004).

\section{CONCLUSION}

According to Natalia (2020), there are 22 articles focused on water consumption and their determinants in hotels. The water usage in tourism is divided into two types: direct usage, for example in accommodation and during tourist activities; and indirect usage particularly for tourists' food-related needs and fuel use.

The main factor to determine the water usage or consumption is the hotel's infrastructure (Tortella and Tirado, 2011), and the role and water tariffs in water consumption (Razumova et al., 2016).

Lastly, this article concludes by emphasising the importance of improving and enhancing the existing water resources policies in order to conserve nature while promoting sustainable tourism industry.

\section{CONTRIBUTION/PRACTICAL IMPLICATIONS}

These findings can contribute to efficiently manage the water in the tourism industry, focusing on hotels to achieve sustainable water resource in the future. Additionally, better knowledge of hotels' water usage might help cope with freshwater scarcity, which is one of "the challenges that humanity faces" (United Nations, 2015).

Awareness on water conservation is also highly critical in tourism sector in order to improve their strategies to manage the limited resources in the future with sustainable manner. 


\section{REFERENCES}

Deyà-Tortella, B., Garcia, C., Nilsson, W., \& Tirado, D. (2019). Hotel water demand: The impact of changing from linear to increasing block rates. Water, 11(8), 1604. doi: 10.3390/w11081604.

Natalia Antonova, Ines Ruiz-Rosa. (2020). Water resources in the hotel industry: A systematic literature review. International Journal of Contemporary Hospitality Management, 33(2), 628 - 649. ISSN: 09596119.

Razumova, M., Rey-Maquieira, J., \& Lozano, J. (2016). The role of water tariffs as a determinant of water saving innovations in the hotel sector. International Journal of Hospitality Management, 52, 78-86. doi: 10.1016/j.jhm.2015.09.011. 